\title{
Reform of "3+3 Promotion" Teaching Model Based on CDIO -- Taking the Course of "Business English Correspondence" as an Example
}

Chao Cong

Guangzhou Railway Polytechnic, Guangzhou 510440, Guangdong Province, China

Funding: The 10th batch of education and teaching reform projects in universities in Guangzhou, research on the training model of international railway logistics personnel from the perspective of "cross-cultural" (project number: 2019JG252) (hosted by Cong Chao).

\begin{abstract}
According to the characteristics of vocational students' limited knowledge of English and poor learning initiative and the English correspondence courses of foreign trade, it is necessary to propose teaching model reform based on the review of existing teaching reforms. Based on the CDIO concept, the " $3+3$ Promotion" teaching model reform is conducted. The questionnaire feedback indicates that students have improved their basic abilities, being more willing to participate in the classroom. Through school-enterprise cooperation, students and enterprises has a win-win situation. Students are satisfied with the overall evaluation of the classroom. Meanwhile, the teachers' professional abilities have been improved. Enterprise resources also need to be further expanded; a conclusion is drawn that the reform of teaching mode is effective and that it is feasible for enterprises to participate in the teaching process.
\end{abstract}

Key words: CDIO; $3+3$ promotion; Foreign trade English correspondence

Publication date: December, 2020

Publication online: 31 December, 2020

"Corresponding author: Chao Cong, 962066821@ qq.com

\section{Introduction}

\subsection{The characteristics of the correspondence course}

From the perspective of international business practice, English correspondence is still the mainstream at present. So, the cultivation of reading and writing skills in teaching activities is also very important in addition to the cultivation of English listening and speaking skills. English is an important tool for international trade services. Correspondence is the process of writing letters of international trade practice in English. By experiencing the specific methods of each link of international trade, students will be proficient in the basic skills of international trade while improving their English. They will cultivate and improve the ability of international trade.

\subsection{The main teaching reforms of current corres- pondence courses}

Wu Liyuan (2017) analyzed the profession, scope, and practicality of the correspondence course. Incumbent teachers are still mechanically imparting knowledge and theory in class, so vocational students are poor in English. In this context, Wu proposed to 
change the teaching content, strengthen practice, and adopt "Situational Simulation Method" and other teaching reforms ${ }^{[1]}$. Cheng Yu and Zeng Rugang (2017) proposed that the "skills decomposition training model" of the "Foreign Trade English Correspondence" course was transformed into a "complete task-centered" classroom teaching model. In the past, a single chapter was used as the teaching module, while foreign trade business as a whole and the cohesiveness of correspondence and communication was ignored, so the separated training is transformed into the integrated task ${ }^{[2]}$. This is also an issue on which we pay more attention in the teaching reform. In particular, the author puts forward the "cube model diagram of the complete task teaching design" for our reference, but the reform is still the task-oriented teaching method which is difficult to mobilize the enthusiasm of students, with barely practical links. Ren Zhuojun, Wang Lianxiao (2015) tried to use TAFE (Australian Technology and Continuing Education) education concepts and teaching methods as the way to carry out reforms and explorations on teachers, students and teaching effects in the course of "Business English Correspondence" ${ }^{[3]}$. Zhao Fengyu and Jiang Heping (2011) put forward the "simulation company teaching model", focusing on integrating theory with practice, team and periodical teaching. It will realize the mutual transformation of perceptual knowledge and rational knowledge, organically combining classroom teaching and practical activities ${ }^{[4]}$.

\subsection{The characteristics of higher vocational students}

Wen Jiuxiang (2014) pointed out that higher vocational students have learning motivation is vague, and learning adaptability is relatively low. Their learning awareness and method are relied on others ${ }^{[5]}$. Zhao Feng and Zou Zhong (2017) pointed out that higher vocational students are healthy ideologically, but have utilitarianism tendencies. They own strong practical and hands-on ability, but behave bad in academics. They have special and outgoing personality, but with weak self-discipline. There are obvious psychological conflicts and negative emotions and other ideological and behavioral characteristics on them ${ }^{[6]}$.

\section{The "3+3 Promotion" teaching model based on CDIO}

The research of Wang Linhai et al. (2018) shows that the CDIO concept is suitable for oral English teaching, whose teaching effect is significant. And it can bring twice the result with half the effort ${ }^{[7]}$. CDIO represents Conceive, Design, Implement and Operate. It is a summary and abstract expression of "projectbased education and learning" and "practicing while learning". Luo Guangwen (2013) proposed that the CDIO application-oriented talent training model takes the whole process of "conception, design, realization, and operation" as the way to cultivate the scientific knowledge level, individual ability, interpersonal communication skill and product construction ability of higher vocational students. It is a talent training mode focusing the cultivation of ability ${ }^{[8]}$. Based on the literature review, this article proposes a " $3+3$ promotion" teaching model based on CDIO in accordance with the teaching characteristics of higher vocational correspondence courses.

\subsection{C: conceiving}

As shown in Figure 1, when making the basic idea, we mainly consider three aspects: before class, during class, and after class. Pre-class enterprise research is necessary. Only by understanding the company's demand for talents can students' skills be targeted; on the other hand, teacher-student seminar is an important way to help students prepare for class. During the class, with the help of corporate information and teachers to give guidance, we can help students lead the completion of relevant learning content. After class, according to the feedback from the company, teachers give evaluations and then students will be promoted to the next level.

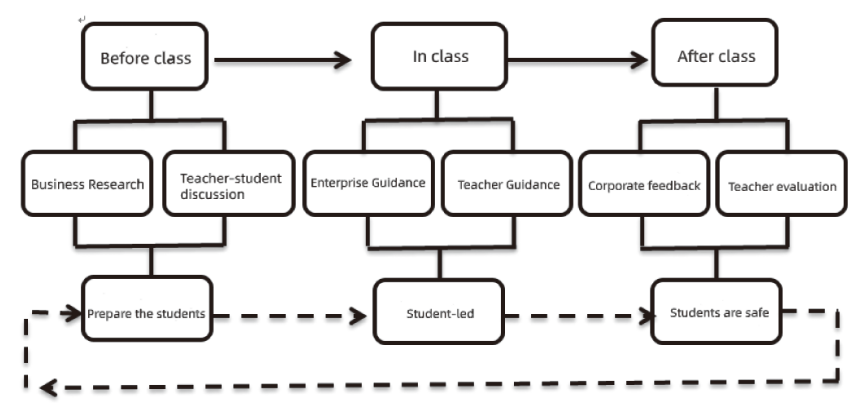

Figure 1. Basic concept map 


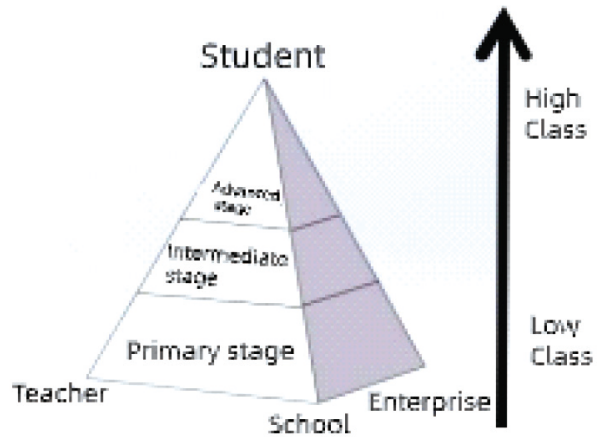

Figure 2. This article studies the " $3+3$ promotion" teaching model

\subsection{D: design of pattern}

According to the characteristics of higher vocational students, the current teaching process is still based on positive encouragement. Maslow's hierarchy of needs theory of the motivational theory is introduced in the teaching model design process, arranging from bottom to top levels. It divides the needs into physiological needs, safety needs, social needs (love and belonging needs), esteem and self-actualization. According to this theory, people's needs are divided into levels and gradually rising in steps. Therefore, in the process of teaching and educating, we should consider the needs of students at different levels by giving different incentives to the needs of students, so as to guide students learn independently to improve the learning effect. Drawing on Maslow's hierarchy of needs theory model diagram, the model diagram 2 studied in this paper is designed.

According to the teaching model in Figure 2, the meaning of the " $3+3$ promotion" teaching model: applying the three basic positions of "school, enterprise, and teacher" to support students' promotion in the three stages of "primary stage, intermediate stage, and advanced stage".

\subsection{I: implementation of plan}

Based on the characteristics of higher vocational students, the current reward methods commonly used by teachers include approval, praise, and registration of normal performance points. These methods have little effect. In the " $3+3$ promotion" teaching model, a hierarchical reward mechanism is adopted for students, and different levels have different promotion standards, making full use of students' "promotional psychology" to formulate the promotion learning plan 1.

Table 1. Study plan for hierarchical promotion

\begin{tabular}{|c|c|}
\hline & $\begin{array}{l}\text { Class Hours: } 32 \text { class hours } \\
\text { Number: } 1 \text { Against } 1 \text { ( } 30 \text { people divided into } 15 \text { groups) } \\
\text { Learning method: Two people a group, respectively act as buyers and sellers, the use of } \\
\text { scenario simulation } \\
\text { Learning content: to set the scene-based, systematic learning of English correspondence content } \\
\text { Promotion Target: Intermediate Stage } \\
\text { Promotion Standard: Basic Command of English letter writing rules, and according to different situations } \\
\text { (enterprises participate in scenario design) with the letter to solve international trade problems. } \\
\text { Number of promotions: } 10\end{array}$ \\
\hline $\begin{array}{l}\text { Intermed } \\
\text { iate } \\
\text { stage }\end{array}$ & $\begin{array}{l}\text { Class Hours: } 20 \text { class hours } \\
\text { Number: } 1 \text { tows } 2(10 \text { leads } 30 \text { ) } \\
\text { Study method: } 10 \text { students who have advanced to the intermediate stage are the team leaders. Each } \\
\text { leader takes } 2 \text { team members and adopts the team teaching method } \\
\text { Learning content: based on the supply information provided by enterprises, try to use English letters and telegrams } \\
\text { to find foreign customers promotion target: Advanced Stage } \\
\text { Promotion Standard: (according to the Enterprise Standard) check whether the writing of correspondence is } \\
\text { standardized, whether the content is accurate, whether the foreign customer has responded. } \\
\text { Number of promotions: } 5\end{array}$ \\
\hline Advanced & $\begin{array}{l}\text { Class Hours: } 12 \text { class hours } \\
\text { Number: } 1 \text { with } 5 \text { ( } 5 \text { with } 30 \text { ) } \\
\text { Learning method: advanced to the stage of } 5 \text { students as a person in charge, } \\
\text { each person in charge with } 5 \text { students, the use of team motivation teaching } \\
\text { method } \\
\text { Leaming content: follour } 1 \text { foreign customer infmation try to condrt customer mainterano promotiongoal: Enterprise parttime } \\
\text { Promotion Standard: (the enterprise participates in the appraisal) the correspondence is smooth, the foreign trade } \\
\text { service is skilled. Promotion number: Enterprises Select } 3-5 \text { people }\end{array}$ \\
\hline
\end{tabular}


Table 2. Table of feedback for improving students' ability of teaching reform

\begin{tabular}{|c|c|c|c|c|c|c|}
\hline \multirow[b]{2}{*}{$\begin{array}{l}\text { Serial } \\
\text { number }\end{array}$} & \multirow[b]{2}{*}{ Questions } & \multicolumn{5}{|c|}{$\begin{array}{l}\text { Degree of acceptance of the following } \\
\text { views }\end{array}$} \\
\hline & & $\begin{array}{c}\text { I } \\
\text { couldn' } \\
\text { t agree } \\
\text { more }\end{array}$ & $\begin{array}{c}\text { I } \\
\text { agree }\end{array}$ & $\begin{array}{l}\text { Pretty } \\
\text { much } \\
\text { agree }\end{array}$ & No & $\begin{array}{c}\text { Not at } \\
\text { all }\end{array}$ \\
\hline 1 & $\begin{array}{l}\text { Through the study of this course, students' cooperative } \\
\text { consciousness is improved }\end{array}$ & 11. $43 \%$ & $48.57 \%$ & $28.57 \%$ & $11.43 \%$ & O\% \\
\hline 2 & $\begin{array}{l}\text { Through the study of this course, students' autonomous, } \\
\text { learning ability is improved }\end{array}$ & 14. $29 \%$ & $37.14 \%$ & $42.86 \%$ & $5.71 \%$ & $0 \%$ \\
\hline 3 & $\begin{array}{l}\text { Through the study of this course, students' English } \\
\text { expression and writing ability are improved }\end{array}$ & 17. $14 \%$ & $37.14 \%$ & $34.29 \%$ & $11.43 \%$ & $O \%$ \\
\hline 4 & $\begin{array}{l}\text { The classroom situation design teaching is advantageous } \\
\text { to enhances the student to analyze the question and the } \\
\text { solution question ability }\end{array}$ & 11. $43 \%$ & $48.57 \%$ & $31.43 \%$ & $8.57 \%$ & OX \\
\hline 5 & $\begin{array}{l}\text { Students were able to participate actively in the lessons } \\
\text { and the results were satisfactory }\end{array}$ & $17.14 \%$ & 45. $71 \%$ & $34.29 \%$ & $2.86 \%$ & $0 \%$ \\
\hline
\end{tabular}

\subsection{O: school-enterprise operation}

School-enterprise cooperation and collaborative education are not only reflected in the employment of students, but can also be integrated into the daily teaching process. Win Choi is a company specializing in the import and export of printed materials. It has a history of more than ten years. The company can provide students with part-time opportunities, pay by the hour, and settle by the day. Students can use their spare time to try to send emails to foreign customers. On the one hand, it can improve students' correspondence writing ability. On the other hand, it can also train students to have a good working attitude and accumulate work experience. The most important thing is to mobilize students' promotion psychology, improve learning effects, and achieve school-enterprise cooperation and education purpose.

\section{The reform practice and effects of the " $3+3$ promotion" teaching model based on CDIO}

\subsection{Through the questionnaire feedback, students have improved their basic abilities.}

Students are full of expectations for the classroom, and are willing to actively participate in the classroom. This teaching reform focuses on organically integrating teaching and practical operations. It refers to corporate information, integrating it into daily teaching, and gradually changing from teacher dominated class to teacher guided class. Teachers can communicate with students, solve problems, and give guidance in a timely manner. The specific results are given feedback through questionnaire surveys.

The questionnaire was conducted by the platform of Questionnaire Star, and the distribution is for the administrative class, so the questionnaire is $100 \%$ effective. Through the feedback from the questionnaire, students generally felt that the overall pressure of studying the course was not great, but more of expectations. Only $17.15 \%$ of students reported that they were stressed out. Through interviews, they learned that the pressure mainly comes from the lack of solid knowledge of international trade. Students have learn course of "International Trade Practice" in the freshmen year. It has been a long time since then. So the forgetting rate of it is high, and the memory is not solid; some students reported that they still have some difficulty in English writing. This is mainly because the English foundation of vocational students is weaker. In term of English mastery, girls are doing better than boys. It can be seen from Table 2 that the new teaching model has a certain improvement in the students' sense of cooperation. $77.14 \%$ of the students basically agree with teamwork, and $11.43 \%$ of the students completely agree with it. We can learn through the interviews that those who completely agree the cooperation are basically the captain or person in charge of the promotion. It is 
very important to lead teamwork for them. Otherwise, there will be pressure for promotion. The students who disagree are basically those with weak English skill, poor initiative or unmotivated promotion; for the improvement of students' independent learning ability, almost everyone agree with it. Only $5.71 \%$ of the students disagree. The main reason is that teachers only provide students with questions and focus on guidance. Students need to learn independently and solve problems by themselves, which increases the difficulty of operation; $11.43 \%$ of the students disagreed with English expression and writing the improvement of ability, which basically reflects the students' current level of English and the need to increase practice in this area. Correspondingly, $17.14 \%$ of the students completely agree. It is relatively high among similar indicators, indicating that our teaching reform has improved students' English expression and writing skills, and there has been a gap between students; students generally state that they are encounter dilemma in analyzing and solving problems, especially for the use of English to accurately express the problem of international trade; In view of students' active participation in the classroom, only $2.86 \%$ of the students disagree, and $17.14 \%$ of the students completely agree. Through interviews, students generally reflect that the class is full of expectations and they are willing to actively participate in the class. The results of the class are good.

\subsection{School-enterprise collaborative education, with schools as the medium}

Enterprises perfectly connect to students to achieve a win-win situation. After the two-way choice between the company and the students, 3 students are doing part-time job in WinChoi, and 2 students are willing to sign an employment agreement with the company. Because they have a certain understanding of the company and business conditions in the early stage, this reduces time for the students adapting to the company.

At the same time, the company has also shortened the training period for the corresponding graduates. Therefore, the common 3-month trial period for employment is shortened to 1 month. After a onemonth transition period, the company will become a full-time employee. It is a win-win situation.

Through the questionnaire survey, it is found that students are still very interested in schoolenterprise cooperation. $80 \%$ of students are willing to use correspondence knowledge to work or do parttime jobs. This is also an aspect that needs to be strengthened in the future.

\subsection{Students are satisfied with the overall evaluation of the classroom and have raised requirements for teachers' professional ability, and corporate resources need to be further expanded.}

It can be seen from the questionnaire that the students are still satisfied with the overall evaluation of the classroom. Among them, 20\% are very satisfied, $62.86 \%$ are satisfied, $17.14 \%$ are generally, $17.14 \%$, $0 \%$ are dissatisfied, and $0 \%$ are extremely dissatisfied. The results are consistent with the overall expectation of reform. Meanwhile, in some aspects that need to be improved in the future, students also have their own ideas. $71.43 \%$ of students think it is necessary in school-enterprise connection, and hold a positive attitude; and $48.57 \%$ of students think that the it is too difficult, especially for solving the problem which is stressful and unsure. Some students still have no confidence in English expression and writing.

Of course, the reform also puts forward new requirements for teachers. Traditional teaching is mainly for teachers as a dominant part. The reform of the " $3+3$ promotion" teaching model can mobilize students to actively participate in the classroom. Thereby, students' expectations of teachers have also increased. After school-enterprise cooperation, we send emails based on corporate information. Teachers must be able to give guidance to students at any time. This requires teachers to check risks first, and the pressure on teachers will increase, and teachers need to continuously improve themselves.

\section{Conclusion}

\subsection{Based on CDIO's " $3+3$ promotion" teaching model reform, the effect is remarkable.}

With changes in the international economic market and constant frictions, English correspondence and telecommunications are the main communication method. They have both traditional importance and new characteristics of the times. This poses new challenges for students who learn to master the use of correspondence and telecommunications. Higher vocational students are poor in English and 
spontaneous learning awareness. As a teacher, how to improve the effect of correspondence learning is an urgent problem to be solved.

Based on the CDIO concept, the article makes full use of the students' promotion psychology, and proposes a " $3+3$ promotion" teaching model reform of schools, enterprises, and teachers. Through questionnaires, students can actively participate in the classroom and have a strong interest in schoolenterprise cooperation. They are mainly satisfied, and the effect is remarkable.

\subsection{The practice of enterprises participating in the teaching process is feasible.}

On the one hand, the company provides real information for the teaching process, which is more authentic than any form of scenario simulation. Students will also attach great importance to it instead of simply coping. Of course, students can also feel the actual work situation of the company most truly, and accumulate business experience while learning. It might provide help for future internships and employment; on the other hand, companies let students do some work with low-risk, low-return, and it requires a lot of manpower. It also reduces the cost of the company. At the same time, it is feasible for enterprises to reserve talents, reduce the transition period of enterprise employment, and shorten the trial period. That is how we can achieve a win-win situation.

\section{References}

[1] Wu LY. Research on the teaching reform strategy of "Foreign
Trade Correspondence" in the vocational education system [J]. Journal of Jishou University (Social Science Edition), 2017, (38): 186-188

[2] Cheng Y, Zeng RG. Research on the complete task classroom design based on the improvement of the professional ability of higher vocational students--Taking the course of international trade practice major "Foreign Trade English Correspondence" as an example [J]. Vocational Education Forum, 2017, (35): 54-58

[3] Ren ZJ, Wang LX. The practice and exploration of TAFE education mode on improving the teaching quality of "Foreign Trade English Correspondence"--Taking Zhejiang Vocational and Technical College of Industry and Commerce as an example [J]. China Adult Education, 2015, (3): 140- 143

[4] Zhao FY, Jiang HP. The application research of simulation company teaching mode in foreign trade English correspondence teaching [J]. Education and Vocation, 2011, (36): 149-150

[5] Wen JX. Research and practice of higher vocational education countermeasures based on students' learning characteristics [J]. Education and Vocation, 2014, (5): 173-174

[6] Zhao F, Zou Z. Some thoughts on innovative ideological education models based on the characteristics of higher vocational students [J]. Ideological Education Research, 2017 (6): 115-117

[7] Wang LH, Zhao M, Yang WW. An Empirical Study on the Flipped Classroom Teaching Model of College Spoken English under the CDIO Concept [J]. Foreign Language Audio-visual Teaching, 2018 (2): 72-77

[8] Luo GW. Research on the training model of applied English professionals in higher vocational colleges based on the concept of CDIO [J]. Educational Theory and Practice, 2013 (24): $27-29$ 